genetics. Dr. Roper graduated in chemistry at Sheffield in 1945, and was trained in bacterial biochemistry under Krebs and MeIlwain. He joined the Genetics Department at Glasgow in 1948 and played a very important part in the development of that school of genetics. For his ability as a teacher, and his engaging personality, he is well liked by the students. At Glasgow he introduced, with great success, group discussion methods. Dr. Roper was Rockefeller Fellow in 1953 at the California Institute of Technology, and has lectured at various times in a number of American and European universities. $\mathrm{H}_{\theta}$ is secretary of the Genetical Society.

Dr. Roper's training in chemistry and microbial biochemistry was a good foundation for the research in microbial genetics on which he embarked at Glasgow. He played a major part there in a team working on the genetics of Aspergitlus nidulans. A most decisive contribution was the first deliberate search for, and his demonstration of, what could be called the 'splitting of the gene' (Nature, 166, 956; 1950). Soon after he designed a way of synthesizing heterozygous diploid strains in filamentous fungi. This was the first step which made possible the discovery of the 'parasexual' cycle and the development of genetic analysis via mitotic segregation. In the past three years Dr. Roper has become interested in investigating extra-nuclear inheritance in Aspergillus. Dr. Roper's ability in teaching and research will be given full opportunities in this new chair, born in a most favourable environment.

\section{The Animal Health Trust}

H.M. THE QUEEN has graciously consented to become patron of the Animal Health Trust. The Trust was founded by Dr. W. R. Wooldridge in 1942 for the purpose of improving the general health standards of all types of domesticated animals, and it approaches the task in two ways. First, by means of scientific investigation of the many disease problems of such animals; secondly, by stimulating the flow of trained personnel into the ranks of the veterinary profession through financial grants to needy students and by furthering the higher educa. tion and specialization of veterinary graduates. Four research centres have been established by the Trust for the study of disease in horses, dogs, poultry and farm animals, respectively, the latest of which-the Farm Livestock Research Centre at Stock, Essexwas opened by H.R.H. Prince Philip in Dacember 1957 (see Nature, 181, 76; 1958). A now surgical unit to mark the patronage of the Queen is to be built at the Equine Research Station, Newrnarket, at a cost of about $£ 30,000$.

\section{The Office of the Lord Privy Seal}

WITH the appointment of Lord Hailsham as the Minister with general responsibility for science and technology, including atomic energy, the Atomic Energy Office and the Lord President's Office will be combined. The new Office will be in the charge of Mr. F. F. Turnbull, whose appointment as deputy secretary, to succe日d Sir Friston How in charge of the Atomic Energy Office, was announced some months ago. It will be organized in two Divisions: (1) a General Division, under Mr. R. N. Quirk, under-secretary, corresponding to the previous Lord President's Office; and (2) an Atomic Energy Division, under Mr. M. I. Michaels, under-secretary, corresponding to the previous Atomic Energy Office.

\section{Parliamentary Responsibility for Science and Tech- nology}

The Prime Minister made a statement in the House of Commons on October 30 regarding the responsibilities of the Lord Privy Seal and the Minister for Science, stating that other Ministers would remain responsible for the scientific establishments within their own Departments, but that the Minister for Science was to be responsible for broad questions of scientific policy outside the sphere of defence, and was advised by the Advisory Council on Seientific Policy on general questions which relate to the whole field of civil science. On November 3, Mr. Macmillan indicated that the arrangements for answering questions in the House of Commons which fall within the responsibility of the Minister for Science would be as follows : questions about the Medical Research Council and radiobiological hazards, the Minister of Health; Agricultural Research Council and Nature Conservancy, the Minister of Agriculture; nuclear energy, the Department of Scientific and Industrial Research and general scientific matters, the Minister of Education; space research, the Minister of Aviation. Where questions about the development of nuclear energy relate to matters for which some other Minister is responsible, that Minister would answer them. For example, questions about nuclearpowered merchant shipping would normally be answered by the Minister of Transport, and about nuclear power stations by the Minister of Power. Mr. Macmillan had earlier defended the exclusion of the new Minister of Power from the Cabinet, but neither that arrangement nor those for answering questions for the Minister of Science in the House of Commons were well received.

\section{Scientific Developments in Britain}

REPLYING to a question in the House of Commons on November 2, Mr. J. B. Godber, as representing the Lord Privy Seal, said that a small temporary station is to be established near Cambridge to expand the work already being done at the Low Temperature Research Station and elsewhere, and he hoped it would be in operation by the end of next year. Meanwhile, the Agricultural Research Council is considering the wider issues raised by the proposal to establish a permanent centre for meat research. In a written answer on November 5, the Minister of Education, Sir David Eccles, as representing the Minister for Science, stated that the new Hydrodynamics Laboratory of the National Physical Laboratory had cost about $£ 2$ million, and its staff was nearly 70 , including 10 scientific officers. The Laboratory would provide up-to-date facilities for testing ship designs, particularly in reproducing more realistic sea conditions, and research would be conducted to extend basic knowledge of the resistance, propulsion and sea-going qualities of ships, while new ship designs would be tested for industry.

In a written reply to a further question on November 5 , Sir David Eccles said that commissioning trials of the fast reactor at Dounreay had proved more difficult than expected, due to chemical engineering problems, but enriched uranium is now being loaded and the reactor is expected to become critical within the next few weeks. This reactor, he said, is an experiment in the development of fast breeder systems, and successful exploitation will depend upon the operating results: the development of the fast reactor will occupy the resources of the Dounreay 